\title{
Effects of Toxin Binder Biotox on Growth Performance Survival, Enzymatic Activity, Hematologichal and Biochemical Parameters of Fingerlings Rainbow Trout (Oncorhynchus mykiss) Fed Diets- Contaminated with Aflatoxin
}

\author{
Mohsen Mohamadi Saei*, Hadis Mansouri Taee ${ }^{2}$, Sokaine Siahpoust ${ }^{3}$ and Majid Taheri ${ }^{3}$ \\ ${ }^{1}$ Lorestan Agricultural and Natural Resources Research and Education Center, AREEO, Khorramabad, Iran \\ ${ }^{2}$ Fisheries Gorgan University of Agricultural Sciences and Natural Resources, Gorgan, Iran \\ ${ }^{3}$ Research and Development Expert Division, Arya Dalman. Co, Tehran, Iran
}

\begin{abstract}
The aim of the study was to determine the effect of Biotox on growth performance, survival, enzymatic activity, hematological and biochemical parameters of fingerlings rainbow trout fed with aflatoxin. For this purpose, 900 fish were stocked in four treatments at the pools and fed 4 times a day by supplementing the basal diet with $0.1 \%$ Biotoxin $^{+1} \mathrm{mg} / \mathrm{kg}$ aflatoxin (T1), $0.2 \%$ Biotoxin $+1 \mathrm{mg} / \mathrm{kg}$ aflatoxin (T2), $1 \mathrm{mg} / \mathrm{kg}$ aflatoxin (T3) and basal diet as control group (T4) for 60 days. There were significant differences $(P<0.05)$ in survival in fish fed different diets for 60 days. Survival was higher in the T2. there were no significant difference $(P>0.05)$ was observed in growth performance, activity Alkaline Phosphatase (ALP) and hematological parameters, of fish in different treatments. Also, no significant difference $(P>0.05)$ in serum globulin, albumin and total protein was observed between treatments and control group. The results of the present study showed a significant $(P<0.05)$ increase in Glucose and triglyceride in T3, whereas serum cholesterol was higher in T3 and control group. Addition of 1-2 g Biotox/ $\mathrm{kg}$ feed did not affected growth performance and hematological parameters, but increased survival of fingerling fed with the diets of aflatoxin B1-exposed.
\end{abstract}

Keywords: Biotox; Growth performance; Enzymatic activity; Rainbow trout; Aflatoxin

\section{Introduction}

Aflatoxins are produced by Aspergillus fungi, which can infect many potential feedstuffs as corn, peanuts, rice, fish meal, shrimp and meat meals [1]. The aflatoxin B1 (AFB1) is very toxic and exists in a wide range of mycotoxins. Its high toxicity to both animals and humans makes AFB1 the most dangerous mycotoxin [2]. Liver is the target organ of aflatoxin B1, long-term intake of diets containing AFB1 can cause a reduction of weight gain, growth stunting and immunosuppression in animals, while increasing hepatocellular carcinoma incidence [3]. It seems that effects of aflatoxins on fish depend on the fish species and age, as fish fry are more susceptible than adults and species like Rainbow trout, (Onchorhynchus mykiss) and European seabass, (Dicentrarchus labrax) seem to be more susceptible than channel catfish, (Ictalurus punctatus) [4-6]. These species specific differences can be attributed to differences in the metabolism of AFB1 in the liver and affinity of AFB1-derived metabolites to hepatic macromolecules [7]. The negative effcts of aflatoxin in different species such as Rainbow trout, Baltic salmon (Salmo salar), Nil tilapia (Oreochromis niloticus), coho salmon (Oncorhynchus kisutch), and Red Drum (Sciaenops ocellatus) [4,8-11] and shrimp (Litopenaeus vannamei) have been demonstrated. There are a number of approaches that can be taken to protect of animal from toxic effect of aflatoxins and these involve prevention of fungal growth, and strategies to reduce or eliminate mycotoxins from contaminated feeds, such as physical, chemical, nutritional, and biological techniques [12]. In the feed industry, the most common method to control AFB1 is the application of nonnutritive adsorptive materials so as to reduce the concentration of fungal toxins in the gastrointestinal tract of animals [13]. The aim of these additives is to inhibit the uptake of mycotoxins by an animal in vivo. The use of mycotoxin binding agents is occasionally recommended to farmers in order to protect animals against the harmful effects of mycotoxins occurring in contaminated feeds. The efficacy of the adsorption appears to depend on the chemical structure of both the adsorbent and the mycotoxin [14,15]. Most studies related to the alleviation of mycotoxicosis by the use of adsorbents are focused on aluminosilicates, mainly zeolites, and aluminosilicate-containing clays, all consisting of aluminates, silicates and some interchangeable ions, mainly alkali metal and alkaline earth metal ions [14,16,17]. Mineral clay products such as bentonites, zeolites, and aluminosilicates are the most common feed additives which are effective in binding/ adsorbing aflatoxins [15]. In the other hand, yeast or yeast cell walls show a potential as mycotoxin binders Besides its excellent nutritional value [14]. Biotox is one of the mycotoxin adsorbing agent and consists of various silicates combined with extracts of the cell walls of a yeast (Saccharomyces cerevisiae) that we have used in our study.

The number of studies addressing the effects of the addition toxin binders to fish feed is very limited. More research is needed to better understand the potential effects of these compounds in diet. Therefore, in the present study attempted was conducted to examine the influence of aflatoxin on growth performance, survival, enzymatic activity, hematological and biochemical parameters of fingerling rainbow trout (Oncorhynchus mykiss) and the antitoxic effect of Biotox.

*Corresponding author: Mohsen Mohamadi Saei, Lorestan Agricultural and Natural Resources Research and Education Center, AREEO, Khorramabad, Iran, Tel: +98 173222 0321; E-mail: mohsenmohamadi57@gmail.com

Received December 23, 2016; Accepted January 19, 2017; Published January 21, 2017

Citation: Saei MM, Taee HM, Siahpoust S, Taheri M (2017) Effects of Toxin Binder Biotox on Growth Performance Survival, Enzymatic Activity, Hematologichal and Biochemical Parameters of Fingerlings Rainbow Trout (Oncorhynchus mykiss) Fed Diets-Contaminated with Aflatoxin. J Aquac Res Development S2: 013 doi:10.4172/2155-9546.S2-013

Copyright: (C) 2017 Saei MM, et al. This is an open-access article distributed unde the terms of the Creative Commons Attribution License, which permits unrestricted use, distribution, and reproduction in any medium, provided the original author and source are credited. 
Citation: Saei MM, Taee HM, Siahpoust S, Taheri M (2017) Effects of Toxin Binder Biotox on Growth Performance Survival, Enzymatic Activity, Hematologichal and Biochemical Parameters of Fingerlings Rainbow Trout (Oncorhynchus mykiss) Fed Diets-Contaminated with Aflatoxin. J Aquac Res Development S2: 013. doi:10.4172/2155-9546.S2-013

Page 2 of 5

\begin{tabular}{|c|c|c|c|}
\hline Ingredient (\%) & Basal diet & Proximate composition (\% wet weight) & Basal diet \\
\hline Fishmeal & 50 & Crud protein & 44.00 \\
\hline Soybean meal & 20 & Lipid & 13.00 \\
\hline Wheat flour & 12 & Moisture & 11.00 \\
\hline Fish oil & 10 & Ash & 13.00 \\
\hline Vitamin premix ${ }^{a}$ & 2 & - & - \\
\hline Mineral premix ${ }^{b}$ & 1.5 & - & - \\
\hline Filler & 4.5 & - & \\
\hline
\end{tabular}

Table 1: The ingredient and proximate composition of basal diet.

\section{Materials and Methods}

\section{Diet experimental design}

Commercial trout diet as basal diet was purchased from Chineh Company, Tehran, Iran. Biochemical analysis of basal diet and treatmen diets showed in Table 1. Biotoxin and AFB1 (C17H12O6, MW- 312.27, 98\% pure) were purchased from Aria trading company Dallman (exclusive representative Biochem, Germany). four experimental diets were prepared by supplementing the basal diet with $0.1 \%$ Biotoxin +1 $\mathrm{mg}$ AFB1/kg (T1), 0.2\% Biotoxin +1 mg AFB1/kg (T2), $1 \mathrm{mg}$ AFB1/kg (T3) and basal diet as control group (T4).

The aflatoxin B1 was dissolved in chloroform and then added to Celufil, a non-nutritive bulking agent. The chloroform was evaporated in the dark under a fume hood. All dry ingredients (exception of the AFB1) was blend in a V-mixer, for $20 \mathrm{~min}$. The dry ingredients were then mixed with the AFB1 in a Hobart mixer. The oil component and water were further added to the dry ingredients and mixed for $1 \mathrm{~h}$. Pellets are maintained in the refrigerator at $4^{\circ} \mathrm{C}$ until use.

\section{Fish and experimental condition}

Water quality parameters such as temperature and dissolved oxygen were measured daily by Thermometer and oxygen meter (Model WTW320I), respectively. They were kept under optimal range.

Nine hundred rainbow trout fingerlings (average weight $10 \pm 0 / 05$ g) were purchased from Private detective propagation and rearing of salmon (Lorestan, Iran). In this study, 9 Concrete pools $(0.8 \mathrm{~m} \times 4 \mathrm{~m} \times$ $2 \mathrm{~m}$ ) were designed. three feeding treatments (T1, T2 and T3) and one pool as control were conducted.

Three replicates were maintained for each treatment. Each pool was connected to a flow-through water system. After an initial 14 days acclimation period, fingerlings were randomly distributed in pools (100 fingerlings per pool).

Fingerlings were fed based on their body weight and temperature 4 times $(06: 00,12: 00,18: 00$ and $24: 00)$ a day at $3 \%$ of body weight for a period of 60 days.

\section{Growth performance and survival rate}

Growth performance, weight and length of Fish (20 fish per pool) was monitored once every 15 days following a 12-h starvation until the end of experiment. Growth performance and survival rate of the fingerlings rainbow trout were calculated using the following Formula:

$$
S G R \% d-1(\text { Specific growth rate })=(\text { LnWt }- \text { Ln W0 }) \times 100 / t
$$

GBM $($ Gain of body mass $)=W t-W 0 ;$ Survival rate $=100 \times(N t / N 0)$

Where: Wt and W0: final and initial body weight $(\mathrm{g})$; t: time of rearing (days); $\mathrm{Nt}$ and $\mathrm{N} 0$ : final and initial fish number.

\section{Blood sampling}

After a 60-day rearing period, five fish from each treatment (three from each tank) were quickly anesthetized using Clove powder (200 $\mathrm{mg} / \mathrm{l}$ ) then body surface of fingerlings rainbow trout were cleaned with blotting paper to avoid any contamination. Blood was collected using a hypodermic syringe from the caudal blood vessels [18]. The blood samples were transferred to heparinized tubes for hematological parameters and non-heparinized tubes to obtain serum for biochemical parameters. The blood was centrifuged at $3,000 \mathrm{rpm}$ for $10 \mathrm{~min}$ at $4^{\circ} \mathrm{C}$ based on Pradhan et al. [19] and Nelson and Somogyi [20]. The collected plasma and serum were stored at $-70^{\circ} \mathrm{C}$ for further analyses.

\section{Hematological parameters}

Red blood cells (RBCs) and white blood cells (WBCs) were counted under a light microscope using a Neubauer hemocytometer with Hayem's solution as the diluting fluid for RBC and Truck's solution for WBC [19,21]. The hemoglobin $(\mathrm{Hb})$ concentrationwas analysed following the cyanmethemoglobin method [22]. Hematocrit (Hct) was determined by centrifuging blood in heparinized microhematocrit capillary tubes at 3,500 rpm for $10 \mathrm{~min}$ [23]. The relative numbers of the types (lymphocytes, neutrophils and monocytes) in the stained peripheral blood were recorded [24], and the percentage of each blood type was calculated as the average blood cell type/sum of averages of all types of blood cells $\times 100$ [25].

\section{Serum biochemical factors}

Biochemical indices, including glucose, total protein, albumin, triglyceride and cholesterol in serum were analyzed using commercial kit (Pars Azmun Co. Ltd., Tehran, Iran) and measured by a spectrophotometer (Model WAP-S2000-UV/VIS, Cambridge-UK) following the manufacturer's instructions $[20,26]$. Globulin levels are calculated by subtracting the amount of albumin from total protein [27].

\section{Enzymatic assays}

Alkaline Phosphatase (ALP) was assayed using commercial kit (Pars Azmun Co. Ltd., Tehran, Iran) and measured by an autoanalyzer. ALP was measured an autoanalyzer according to Bessey et al. [28].

\section{Data analysis}

All data are shown as mean \pm SD (standard deviations). Normality of data was tested by Shapiro-Wilk's test. Data were subjected to oneway ANOVA and significant difference between the treatments was determined by Duncan's test. The values of $\mathrm{P}<0.05$ were considered significantly different. All analyses were performed using statistical software SPSS (version, 17).

\section{Results}

The growth performance and survival of fingerlings rainbow trout 
Citation: Saei MM, Taee HM, Siahpoust S, Taheri M (2017) Effects of Toxin Binder Biotox on Growth Performance Survival, Enzymatic Activity, Hematologichal and Biochemical Parameters of Fingerlings Rainbow Trout (Oncorhynchus mykiss) Fed Diets-Contaminated with Aflatoxin J Aquac Res Development S2: 013. doi:10.4172/2155-9546.S2-013

Page 3 of 5

\begin{tabular}{|c|c|c|c|}
\hline Variables & GBM(g) & SGR (\%) & Survival (\%) \\
\hline T1 & $77.20 \pm 8.96^{\mathrm{a}}$ & $2.21 \pm 0.15^{\mathrm{a}}$ & $2.28 \pm 0.37^{\mathrm{a}}$ \\
\hline T2 & $77.78 \pm 0.85^{\mathrm{a}}$ & $2.14 \pm 0.23^{\mathrm{a}}$ & $100 \pm 0.00^{\mathrm{a}}$ \\
\hline T3 & $65.64 \pm 11.47^{\mathrm{a}}$ & $2.16 \pm 0.23^{\mathrm{a}}$ & $97.00 \pm 0.00^{\mathrm{b}}$ \\
\hline Control & $74.14 \pm 11.06^{\mathrm{a}}$ & $98.00 \pm 1.73^{\mathrm{ab}}$ & $2.15^{\mathrm{ab}}$ \\
\hline
\end{tabular}

Table 2: Effects of Biotox on Growth performance and Survival of $O$. mykiss fed with the diets of $1 \mathrm{mg} \mathrm{AFB} 1 / \mathrm{kg}$-exposed at the end of feeding trial.

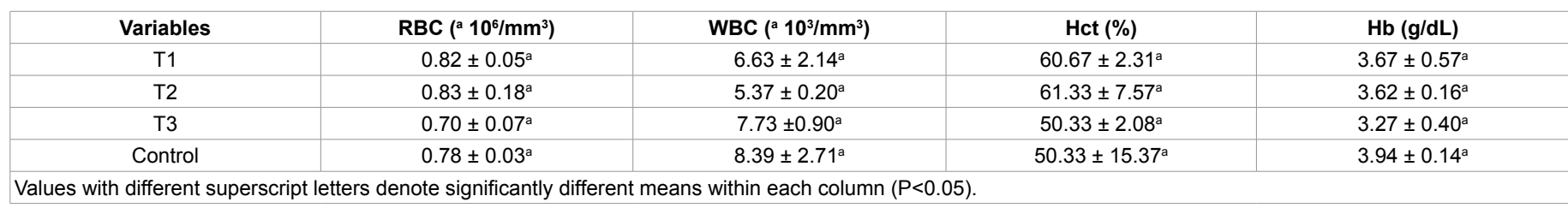

Table 3: Effects of Biotox on hematological parameters of $O$. mykiss fed with the diets of $1 \mathrm{mg} \mathrm{AFB1/kg-exposed} \mathrm{at} \mathrm{the} \mathrm{end} \mathrm{of} \mathrm{feeding} \mathrm{trial.}$

\begin{tabular}{|c|c|c|c|}
\hline Variables & Monocytes & Neutrophils & Lymphocytes \\
\hline $\mathrm{T} 1$ & $0.67 \pm 1.15^{\mathrm{a}}$ & $4.00 \pm 6.92^{\mathrm{a}}$ & $95.33 \pm 8.08^{a}$ \\
\hline $\mathrm{T} 2$ & $0.00 \pm 0.00^{a}$ & $6.67 \pm 7.02^{\mathrm{a}}$ & $93.33 \pm 7.02^{\mathrm{a}}$ \\
\hline T3 & $0.00 \pm 0.00^{\mathrm{a}}$ & $4.67 \pm 6.43^{a}$ & $94.00 \pm 8.71^{a}$ \\
\hline Control & $1.33 \pm 2.31^{a}$ & $2.67 \pm 2.31^{a}$ & $96.00 \pm 4.00^{\mathrm{a}}$ \\
\hline
\end{tabular}

Table 4: Effects of Biotox on the percentage of the lymphocytes, neutrophils and monocytes in O. mykiss fed with the diets of $1 \mathrm{mg}$ AFB1/kg-exposed at the end of feeding trial.

\begin{tabular}{|c|c|c|c|c|c|c|}
\hline Variables & $\begin{array}{l}\text { Glucose } \\
\text { (mg/dl) }\end{array}$ & $\begin{array}{l}\text { Triglyceride } \\
\text { (mg/dl) }\end{array}$ & Cholesterol (mg/dl) & $\begin{array}{c}\mathrm{TP} \\
(\mathrm{mg} / \mathrm{dl})\end{array}$ & Albumin (mg/dl) & Globulin (mg/dl) \\
\hline $\mathrm{T} 1$ & $143.00 \pm 2.64^{\mathrm{ab}}$ & $305.67 \pm 4.04^{b}$ & $253.33 \pm 8.32^{\mathrm{ab}}$ & $5.85 \pm 0.08^{a}$ & $2.01 \pm 0.39^{a}$ & $3.84 \pm 0.34^{a}$ \\
\hline $\mathrm{T} 2$ & $134.67 \pm 3.05^{\mathrm{b}}$ & $295.33 \pm 5.51^{c}$ & $240.00 \pm 13.23^{b}$ & $5.92 \pm 0.04^{a}$ & $2.09 \pm 0.38^{a}$ & $3.83 \pm 0.41^{a}$ \\
\hline T3 & $146.33 \pm 3.78^{a}$ & $318.67 \pm 7.77^{\mathrm{a}}$ & $271.67 \pm 10.40^{a}$ & $5.84 \pm 0.02^{\mathrm{a}}$ & $1.96 \pm 0.31^{\mathrm{a}}$ & $3.87 \pm 0.33^{a}$ \\
\hline Control & $145.00 \pm 9.53^{\mathrm{ab}}$ & $312.67 \pm 2.52^{\mathrm{ab}}$ & $268.33 \pm 7.64^{a}$ & $5.82 \pm 0.09^{a}$ & $1.60 \pm 0.10^{\mathrm{a}}$ & $4.22 \pm 0.16^{\mathrm{a}}$ \\
\hline
\end{tabular}

Table 5: Effects of Biotox on biochemical blood parameters of $O$. mykiss fed with the diets of $1 \mathrm{mg}$ AFB1/kg-exposed at the end of feeding trial.

\begin{tabular}{|c|c|}
\hline Variables & ALP (U/L) \\
\hline T1 & $577.89 \pm 93.26^{\mathrm{a}}$ \\
\hline T2 & $623.28 \pm 42.59^{\mathrm{a}}$ \\
\hline T3 & $726.65 \pm 139.83^{\mathrm{a}}$ \\
\hline Control & $594.67 \pm 26.25^{\mathrm{a}}$ \\
\hline
\end{tabular}

Values with different superscript letters denote significantly different means within each column $(P<0.05)$

Table 6: Effects of Biotox on ALP activity of O. mykiss fed with the diets of $1 \mathrm{mg}$ AFB $1 / \mathrm{kg}$-exposed at the end of feeding trial

fed treatment diets is presented in Table 2. No significant difference $(\mathrm{P}>0.05)$ in growth performance was observed in fish fed different diets for 60 days. There were significant differences $(\mathrm{P}<0.05)$ in survival in fish fed different diets for 60 days. survival in the T2 was significantly higher than the T3 $(\mathrm{P}<0.05)$. but there was no significant difference $(\mathrm{P}>$ 0.05 ) between $\mathrm{T} 1$ and control group, between $\mathrm{T} 2$ and $\mathrm{T} 1$, control group and between $\mathrm{T} 3$ and $\mathrm{T} 1$ (Table 2).

Effects of treatment diet on hematological parameters of fingerlings rainbow trout are presented in Table 3 . No significant difference $(\mathrm{P}>0.05)$ in hematological parameters was observed in treatments and control group for 60 days (Table 3). The percentage of the lymphocytes, neutrophils and monocytes showed no significant changes between treatments and control group (Table 4).

Effects of varying doses of dietary Biotoxin and aflatoxin on biochemical blood parameters are shown in Table 5. No significant difference $(\mathrm{P}>0.05)$ in serum Globulin, Albumin and total protein was observed in treatments and control group. Fish fed with T3 and control group showed significantly $(\mathrm{P}<0.05)$ higher Cholesterol contents. The serum Glucose and Triglyceride level were significantly $(\mathrm{P}<0.05)$ increased in $\mathrm{T} 3$ (Table 5).

Effects of different levels of dietary Biotoxin and AFB1 on enzyme activity of fingerlings rainbow trout are presented in Table 6. There was no significant $(\mathrm{P}>0.05)$ effect change in ALP between treatments and control group (Table 6).

\section{Discussion}

There are differences in vulnerability to mycotoxins among salmonid species. For example, rainbow trout is considered very susceptible to AFB1 $[4,8]$. The first documented incidences of aflatoxicosis affecting fish health occurred in the 1960s in trout hatcheries. Domesticated rainbow trout that were fed a pelleted feed prepared with cottonseed meal contaminated with aflatoxins, developed liver tumors and as many as $85 \%$ of the fish died in these hatcheries. Although cottonseed meal is no longer used as a major ingredient in feed formulations, poor storage of other feed ingredients and nutritionally complete feeds can lead to contamination with aflatoxins $[29,30]$. Santacroce et al. [8] explained that dosages of $0.5-1$ AFB1 $\mathrm{mg} / \mathrm{kg}$ feed resulted in $50 \%$ mortality. Other study showed that levels of $0.02 \mathrm{AFB} 1 \mathrm{mg} / \mathrm{kg}$ feed produced $96 \%$ incidence of liver tumors in rainbow trout. However, the same treatment had no effect on coho salmon [4]. In the peresent study survival was low in T3 that indicate the negative effect of AFB1 on survival. Although survival was negatively affected by AFB1, adding $2 \mathrm{~g}$ Biotox $/ \mathrm{kg}$ diet of rainbow trout fingerlings significantly increased survival of the fish. Our results indicated that Biotox especially at higher 
dosage was effective to help improve survival. Previous study showed that the addition of adsorbents to feed can cause reducing aflatoxicosis in animal [31,32]. Also, NovaSil (a calcium montmorillonite clay) supplementation in the diets of AFB1-exposed fish resulted in a protective effect [33]. Other studies have reported that a $2 \%$ inclusion level of bentonite (a common clay containing montmorillonite) in trout feed reduced toxic AFB1 effects [1].

This study showed no significant change on GBM and SGR. While there was a slight increase in growth performance in $\mathrm{T} 1$ and T3, there was not significant. It is possible that the levels of AFB1and/ or Biotox used in this study were not capable of significant effect on growth performance. Sepahdari et al. [34] stated that the negative effect of AFB1 on fish growth seems to be correlated to the amount of toxin and duration of exposure. The toxicity of aflatoxin also varies according to many nutritional factors, and recovery from protein malnutrition is delayed by exposure to aflatoxin [35]. Similary Santacroce et al. [8] stated that the feeds containing $0.5-1$ AFB $1 \mathrm{mg} / \mathrm{kg}$ feed did not affect the growth, feed intake or produced liver damage on Baltic salmon. Another study reported that there were no differences in the evaluated growth performance and feed intake of juvenile salmon exposed to AFB1 doses $0,1,5,10$ or $20 \mathrm{mg} / \mathrm{kg}$ feed [9]. This result is in agrement with our result that aflatoxin at a $1 \mathrm{mg} / \mathrm{kg}$ feed dose cannt chang growth performance in fingerlings rainbow trout. Cagauan et al. [10] reported that when Nile tilapia were fed diets containing $1.8 \mathrm{mg} \mathrm{AFB1/}$ $\mathrm{kg}$ feed for 75 days growth rates reduced. Another study stated that Nile tilapia fed diets that contained 2.5, 10, or $100 \mathrm{mg} \mathrm{AFB} 1 / \mathrm{kg}$ feed for 8 weeks had reduced weight gain [5]. Species-specific differences in vulnerability because of variations in toxin metabolism [7] and dose of exposure to AFB1 contaminated diet could explain the results.

Hematological parameters are important factors that could be considered during the fish diet quality, fish conditions and toxic effect of substances assessment [36]. These factors are considered valuable indices to assess fish health $[37,38]$. Our result showed no change on hematological parameters (RBC, WBC, $\mathrm{PCV}, \mathrm{Hb}$ and $\mathrm{MCV}$ ) as well as the percentage of Lymphocytes, Neutrophils and Monocytes. Mahfouz and Sherif [39] demonstrated that hematological profiles and monocytes, esinophils, and lymphocytes were influenced by the dose and duration of exposure to AFB1 contaminated diet. As RBC, WBC, PCV, $\mathrm{Hb}$ and MCV levels were significantly decreased in the high AFB1 exposed group. Also, Tuan et al. [5] stated that Nile tilapia fed diets that contained $2.5 \mathrm{mg}, 10 \mathrm{mg}$, or $100 \mathrm{mg} \mathrm{AFB1/} \mathrm{kg}$ feed for 8 weeks had reduced red blood cell counts.

ALP is a membrane bound enzyme and its alteration is likely to affect the membrane permeability and produce derangement in the transport of metabolites [40]. An increase of these enzyme activities in the extracellular fluid or serum is a sensitive indicator of even minor cellular damage [41] in which cellular enzymes are released from the cells into the blood serum, which in turn indicates stress-based tissue impairment. Mahfouz and Sherif [39] showed that the activity of serum AST, ALT and ALP liver enzymes significantly increased in tilapia exposed to $100 \mathrm{ppb}$ AFB1. Also, Mahfouz and Sherif [39] verified that AST, ALT and ALP were significantly increased in the serum of rats administered AFB1 $(250 \mu \mathrm{g} / \mathrm{kg} /$ day for 2 weeks) indicating the presence of damaged and dysfunctional liver cells. Our result showed that dosages of $1 \mathrm{mg}$ AFB1 $/ \mathrm{kg}$ feed had no effect on ALP of fingerlings rainbow trout. The diference between our result and the other studies is maybe due to the dose and duration of exposure to AFB1 contaminated diet.

One of the most principal target organs for aflatoxicosis is hepatopancreas [8]. After the invasion of aflatoxin into the hepatopancreas, aflatoxin metabolites react negatively with different cell proteins, which lead to inhibition of carbohydrate, lipid metabolism and protein synthesis, finally inducing hepatopancreas necrosis, cell death or tumour. In relation with the disorder in hepatopancreas function, there is also aderangement of the blood-clotting mechanism, jaundice and adecrease in total serum proteins and cholesterol synthesized by thehepatopancreas [10]. In this study, fish fed in all treatment showed no effect on total serum protein, Albumin, and Globulin. In agremeant, Zeng et al. [42,43] dietary AFB1 had no effect on serum total serum protein and Albumin in white shrimp.

The addition of toxin binder or adsorbents to feed is considered the most promising and economica approach of reducing aflatoxicosis in animals [31,32]. The beneficial effects of using these adjectives in feed have been shown in afew studies. NovaSil (a calcium montmorillonite clay) supplementation in the diets of AFB1-exposed on Red Drum resulted in a protective effect, which was evident by the significant improvement in many of the tested parameters [33]. Ellis et al. [1] have reported that a $2 \%$ inclusion level of bentonite (a common clay containing montmorillonite) in trout feed reduced toxic AFB1 effects. Hassan et al. [44] in their studies suggest that a $0.5 \%$ inclusion level was sufficient to protect tilapia from $1.5 \mathrm{ppm}$ AFB1. In anather study, Bentonites have been added into fish feed at concentrations up to $10 \%$ with no alteration in whole-body proximate composition [45]. In the curent study, addition of 1 and $2 \mathrm{~g}$ Biotox $/ \mathrm{kg}$ feed did not ameliorate the effects of AFB1 on growth performanc and hematological parameters, but increased survival of fingerling rainbow trute. Our result suggest that dietary Biotox may need to be used at levels higher than $1-2 \mathrm{~g} / \mathrm{kg}$ feed to achieve protective effects against aflatoxin.

\section{Conclusion}

In conclusion, Observed difference in different studies indicates differences in fish species, sources response to aflatoxin. Also, the dose and duration of exposure to AFB1 contaminated diet and the dose of Biotox are the other reason for these differeces. Addition of 1-2 $g$ Biotox/ kg feed did not affected growth performance and hematological parameters, but increased survival of fingerling rainbow trute fed with the diets of $1 \mathrm{mg}$ AFB1/ $\mathrm{kg}$-exposed.

\section{Acknowledgments}

The authors would like to thank ARIA DALMAN for providing the necessary facilities for the study.

\section{References}

1. Ellis R, Clements M, Tibbetts A, Winfree R (2000) Reduction of the bioavailability of $20 \mu \mathrm{g} / \mathrm{kg}$ aflatoxin in trout feed containing clay. Aquaculture 183: 179-188.

2. Wilson RW, Bergman HL, Wood CM (1994) Metabolic costs and physiological consequences of acclimation to aluminum in juvenile rainbow trout (Oncorhynchus mykiss). II. Gill morphology, swimming performance, and aerobic scope. Canadian Journal of Fish Aquatic Science 51: 536-544.

3. Mishra HN, Das C (2003) A review on biological control and metabolism of aflatoxin. Food Science Nutrition 43: 245-264.

4. Manning BB (2001) Mycotoxins in fish feeds. In Nutrition and Fish Health. Food Products Press. New York.

5. Tuan NA, Grizzle JM, Lovell RT, Manning BB, Rottinghaus GE (2002) Growth and hepatic lesions of Nile tilapia (Oreochromis niloticus) fed diets containing aflatoxin B1. Aquaculture 212: 311-319.

6. El-Sayed YS, Khalil RH (2009) Toxicity, biochemical effects and residue of aflatoxin B1 in marine water-reared sea bass (Dicentrarchus labrax L.). Food and Chemical Toxicology 47: 1606-1609.

7. Ngethe S, Horsberg TE, Mitema E, Ingebrigtsen K (1993) Species differences in hepatic concentration of orally administered 3H AFB1 between rainbow trout (Oncorhynchus mykiss) and tilapia (Oreochromis niloticus). Aquaculture 114: 355-358. 
Citation: Saei MM, Taee HM, Siahpoust S, Taheri M (2017) Effects of Toxin Binder Biotox on Growth Performance Survival, Enzymatic Activity, Hematologichal and Biochemical Parameters of Fingerlings Rainbow Trout (Oncorhynchus mykiss) Fed Diets-Contaminated with Aflatoxin. J Aquac Res Development S2: 013. doi:10.4172/2155-9546.S2-013

8. Santacroce MP, Conversano MC, Casalino E, Lai O, Zizzadoro C, et al. (2008) Aflatoxins in aquatic species: metabolism, toxicity, and perspectives. Fish Biology and Fisheries 18: 99-130.

9. García EC, Pirhonen J (2013) Effects of fumonisin B1 on performance of juvenile Baltic salmon (Salmo salar). Master's thesis. University of Jyväskylä. Faculty of Science.

10. Cagauan AG, Tayaban RH, Somga J, Bartolome RM (2004) Effect of aflatoxin contaminated feeds in Nile tilapia (Oreochromis niloticus L.). Proceedings of the 6th International Symposium on Tilapia in Aquaculture (ISTA 6). Section: Health Management and Diseases, Manila, Philippines.

11. Zychowski KE, Pohlenz C, Mays T, Romoser A, Hume M, et al. (2013) The effect of NovaSil dietary supplementation on the growth and health performance of Nile tilapia (Oreochromis niloticus) fed aflatoxin-B1 contaminated feed. Aquaculture 376-379: 117-123.

12. Wayne LB (2012) Mycotoxin contamination of the feed supply chain Implications for animal productivity and feed security. Animal Feed Science Technology.

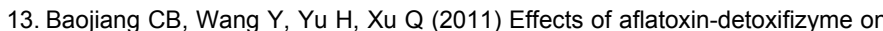
growth performance and liver biochemical indices of broilers fed with aflatoxin B1. Frontiers of Agriculture in China 5: 594-597.

14. Huwig A, Freimund S, Kappeli O, Dutler H (2001) Mycotoxin detoxification of animal feed by different adsorbents. Toxicology Letters 122: 179-188.

15. Avantaggiato A, Solfrizzo M, Visconti A (2005) Recent advances on the use of adsorbent materials for detoxification of Fusarium mycotoxins. Food Additives and Contaminants 22: 379-388.

16. Jaynes WF, Zartman RE, Hudnall WH (2007) Aflatoxin B1 adsorption by clays from water and corn meal. Applied Clay Science 36: 197-2005.

17. Dixon JB, Kannewischer I, Tenorio AMG, Barrientos VAL (2008) Aflatoxin sequestration in animal feeds by quality-labeled smectite clays: an introductory plan. Applied Clay Science 40: 201-208.

18. Trenzado CE, Carrick TR, Pottinger TG (2003) Divergence of endocrine and metabolic responses to stress in two rainbow trout lines selected for differing cortisol responsiveness to stress. General and Comparative Endocrinology 133: $332-340$.

19. Pradhan SC, Patra AK, Sarkar B, Pal A (2012) Seasonal changes in hematological parameters Labeo rohita (Hamilton, 1822). Journal of Applied Ichthyology 30: 48-54

20. Pradhan SC, Patra AK, Pal A (2014) Hematological and plasma chemistry of Indian major car of Catla catla (Hamilton 1822). Comparative Clinical Pathology 21: $1473-1481$

21. Nelson JW, Somogyi M (1945) Determination of glucose. Hawk's physiologica chemistry, (14thedn) McGraw Hill Publication, New York.

22. Akhtar MS, Pal AK, Sahu NP, Ciji A, Mahanta PC (2013) Thermal tolerance, oxygen consumption and haemato-biochemical variables of Tor putitora juveniles acclimated to five temperatures. Fish Physiology and Biochemistry 39: $1387-1398$

23. Blaxhall PC, Daisley KW (1973) Routine haematological methods for use with fish blood. Journal of Fish Biology 5: 771-781.

24. Zexia G, Weimin WY, Abbas K, Dapeng L, Guiwei Z, et al. (2007) Morphological studies of peripheral blood cells of the Chinese sturgeon (Acipenser sinensis). Fish Physiology and Biochemistry 33: 213-222.

25. Burgos-Aceves MA, Campos-Ramos R, Guerrero-Tortolero DA (2010) Description of peripheral blood cells and differential blood analysis of captive female and male leopard grouper (Mycteroperca rosacea) as an approach for diagnosing diseases. Fish Physiology and Biochemistry 36: 1263-1269.

26. Benfey TJ, Biron M (2000) Acut estress response in triploid rainbow trout (Oncorhynchus mykiss) and brook trout (Salvelinus fontinalis). Aquaculture 184: 167-176.

27. Kumar S, Sahu NP, Pal AK, Choudhury D, Yengkokpam S, et al. (2005) Effect of dietary carbohydrate on haematology, respiratory burst activity and histological changes in Labeo rohita juveniles. Journal of Fish and Shellfish Immunology 19: 331-344

28. Bessey OA, Lowry OH, Brock MJ (1946) Rapid coloric method for determination of alkaline phosphatase in five cubic millimeters of serum. Journal of Biological Chemistry 164: 321-329.
29. Ashley LM (1970) Pathology of fish fed aflatoxins and other antimetabolites In: A symposium on diseases of fishes and shellfishes. American Fisheries Society Special Publication 5: 366-379.

30. Russo JAR, Yanong RPE (2013) Molds in fish feeds and aflatoxicosis University of Florida, IFAS Extension FA 95: 1-3

31. Pizzolitto RP, Armando MR, Salvano MA, Dalcero AM, Rosa CA (2013) Evaluation of Saccharomyces cerevisiae as an antiaflatoxicogenic agent in broiler feedstuffs. Poultry Science 92: 1655-1663.

32. Chowdhury SR, Smith TK, Boermans HJ, Sefton AE, Downey R, et al. (2005) Effects of feeding blends of grains naturally contaminated with Fusarium mycotoxins on performance, metabolism, hematology, and immunocompetence of ducklings. Poultry Science 84: 1179-1185.

33. Zychowski KE, Hoffmann AR, Ly HJ, Pohlenz C, Buentello A, et al. (2013) The effect of aflatoxin-B1 on red drum (Sciaenops ocellatus) and assessment of dietary supplementation of NovaSil for the Prevention of Aflatoxicosis. Toxins (Basel) 5: 1555-1573.

34. Sepahdari A, Ebrahimzadeh MHA, Sharifpour I, Khosravi A, Motallebi AA, et al. (2010) Effects of different dietary levels of AFB1 on survival rate and growth factors of Beluga (Huso huso). Iranian. Journal of Fish Science 9: 141-150.

35. Williams JH, Phillips TD, Pauline EJ, Stiles JK, Curtis MJ, et al. (2004) Human aflatoxicosis in developing countries: a review of toxicology, exposure, potential health consequences, and interventions. American Journal of Clinical Nutrition 80: 1106-1122.

36. Svobodova Z, Fravda D, Palakova J (1991) Unified methods of haematologica examination of fish. Research Institute of Fish Culture and Hydrobiology, VURH Vodnany, Edice Metodik, Czechoslovakia.

37. Khajepour F, Hosseini SA, MaHoseini S (2011) Studyon some hematological and biochemical parameters of juvenile beluga (Huso huso) fed citric acid supplemented diet. Global Veterinaria 7: 361-364.

38. Roberts R, Rodger H (1978) The pathophysiology and systematic pathology of teleosts. Fish Pathology 62-143.

39. Mahfouz ME, Sherif AH (2015) A multiparameter investigation into adverse effects of aflatoxin on Oreochromis niloticus health status. Journal of Basic and Applied Zoology 71: 48-59.

40. Hung SSO, Lutes PB, Storebakken T (1989) Growth and feed efficiency of white sturgeon (Acipenser transmontanus) sub yearling at different feeding rates. Aquaculture 80: 147-153

41. Ronyai A, Peteri A, Radics F (1990) Cross breeding of starlet and lena river sturgeon. Aquaculture Hungrica szarwas 6: 13-18.

42. FAO (Food and Agriculture Organization) (2016) Table of an example of a feeding table for Atlantic salmon (\% body weight/day). Food and Agriculture Organization of the United Nations, Rome, Italy.

43. Zeng SL, Long WQ, Tian LX, Xie SW, Chen YJ, et al. (2015) Effects of dietary aflatoxin B1 on growth performance, bodr composition, haematological parameters and histopathology of juvenile Pacific white shrimp (Litopenaeus vannamei). Aquaculture Nutrition 1-8.

44. Hassan AM, Kenawy AM, Abbas WT, Abdel-Wahhab MA (2010) Prevention of cytogenetic, histochemical and biochemical alterations in Oreochromis niloticus by dietary supplement of sorbent materials. Ecotoxicology and Environmental Safety 73: 1890-1895.

45. Eya JC, Parsons A, Haile I, Jagidi P (2008) Effects of dietary zeolites (bentonite and mordenite) on the performance juvenile rainbow trout Onchorhynchus myskiss. Austr Journal of Basic and Applied Science 2: 961-967. 